\title{
Detection and Characterization of $\beta$-Adrenergic Receptors and Adenylate Cyclase in Coated Vesicles Isolated from Bovine Brain
}

\author{
D.-M. Chuang, ${ }^{\star}$ O. Dillon-Carter, ${ }^{*}$ J. W. Spain, $\dagger$ M. B. Laskowski, $\dagger$ B. L. Roth, ${ }^{*, 1}$ and C. J. Coscia $\dagger$ \\ *Laboratory of Preclinical Pharmacology, St. Elizabeth's Hospital, National Institute of Mental Health, Washington, \\ D.C. 20032, and †E. A. Doisy Department of Biochemistry and Department of Physiology, St. Louis University \\ School of Medicine, St. Louis, Missouri 63104
}

To assess whether internalization of $\beta$-adrenergic receptor occurs in the CNS, we have isolated clathrin-coated vesicles from bovine forebrain and examined them for the presence of $\beta$-adrenergic receptor binding and adenylate cyclase activities. $A$ coated vesicle enriched preparation isolated by successive $D_{2} O-$ Ficoll density gradient centrifugations was applied to a glass bead permeation column to achieve further purification. Two major peaks of protein were eluted from the column and monitored by electron microscopy and SDS-PAGE. Peak II contained almost exclusively coated vesicles $(98 \%)$, whereas peak $I$, which appeared in the void volume, contained larger smooth vesicles and few coated vesicles. $\beta$-Adrenergic receptor binding to peaks I and II was measured with ${ }^{125}$ I-cyanopindolol (CYP) as ligand in Sepharose $4 B$ column assays. ${ }^{125}$ I-CYP was found to bind specifically and saturably to both peaks I and II with a $B_{\max }$ of $28 \pm 4$ and $32 \pm 3 \mathrm{fmol} / \mathrm{mg}$ protein, respectively. ${ }^{3} \mathrm{H}$ CGP 12177, a hydrophilic $\beta$-adrenergic receptor ligand, did not label receptors present in peak II, but it specifically bound to synaptic plasma membranes (SPM) prepared from bovine hippocampus and, to a lesser extent, to peak $I$. These results suggest that receptors present in coated vesicles are cryptic in nature. In the displacement of ${ }^{125}$ I-CYP binding by (-)-isoproterenol, addition of $50 \mu \mathrm{M}$ GppNHp caused a significant "right shift" with SPM and peak I but not the peak II preparation. Adenylate cyclase activities could also be detected in both peaks I and II (specific activities, $21 \pm 0.6$ and $24 \pm 0.5 \mathrm{pmol} \mathrm{cAMP} / \mathrm{mg}$ protein/min, respectively). These activities were not influenced by GTP or GTP plus isoproterenol. Rechromatography of peak II on the glass bead column revealed that appreciable amounts of protein, CYP binding, and adenylate cyclase activities could be recovered in peak $I$; this change in chromatographic pattern was facilitated by pretreatment of coated vesicles with $0.5 \mathrm{M}$ Tris, which has been shown to uncoat these vesicles. This suggests that at least some of the protein, as well as CYP binding and cyclase activities, found in peak $I$ originated from coated vesicles following loss of clathrin and aggregation. Our results support the concept that $\beta$-adrenergic receptor and adenylate cyclase detected in coated vesicles are molecular entities undergoing endocytotic or exocytotic intracellular transport.

Coated vesicles, originally described by Roth and Porter (1964), appear to be present in virtually all eukaryotic cells. One of the best defined functions of coated vesicles is that of receptormediated internalization of specific ligands; it has been shown morphologically that they are involved in the uptake of a variety of substances, including low-density lipoprotein, yolk protein,

\footnotetext{
Received Nov. 15, 1985; revised Feb. 10, 1986; accepted Mar. 24, 1986.

Correspondence should be addressed to D. M. Chuang at the above address.

' Present address: Naval Medical Research Institute, Bethesda, MD 20814.

Copyright (C) 1986 Society for Neuroscience $0270-6474 / 86 / 092578-07 \$ 02.00 / 0$
}

transferrin, epidermal, and NGFs, insulin, and immunoglobulins (reviewed by Fine and Ockleford, 1984; Goldstein et al., 1979). In this process, coated vesicles appear to bud from coated pits in the plasma membrane and then rapidly lose their coating to become part of the endosomes or receptosomes before they fuse with intracellular organelles such as lysosomes. It has also been suggested that coated vesicles are involved in the transport of molecules between organelles such as the endoplasmic reticulum and the Golgi apparatus and between the Golgi and the plasma membrane (Bursztan and Fischbach, 1984; Palade and Fletcher, 1977; Rothman and Fine, 1980; Rotundo and Fambrough, 1980). Coated vesicles were first purified to near homogeneity by Pearse (1976) and shown to contain a major protein of $180,000 \mathrm{Da}$ termed clathrin. In addition, 3 prominent groups of polypeptides have been associated with purified coated vesicles isolated from brain and several other tissues. These proteins have molecular weights of approximately 110,000 $100,000,55,000-50,000$, and 38,000-35,000, respectively (Garbern and Wu, 1981; Mello et al., 1980; Pfeffer et al., 1983; Pilch et al., 1983; Rothman and Fine, 1980; Wood et al., 1978). Isolated coated vesicles have been shown to contain molecules such as transferrin, ferritin, and immunoglobulin (Pearse, 1982) and receptors for low-density lipoprotein (Mello et al., 1980), insulin (Pilch et al., 1983), ACh (Porter-Jordan et al., 1982), and opioids (Bennett et al., 1985).

Evidence has accumulatcd suggesting that $\beta$-adrenergic receptor binding sites may be internalized during agonist-induced receptor down-regulation in frog erythrocytes (Chuang and Costa, 1979; Stadel et al., 1983) and several cultured cell systems (Harden et al., 1980; Mahan et al., 1985; Pittman and Molinoff, 1980; Staehelin and Hertel, 1982). In the CNS, $\beta$-adrenergic receptors can be down-regulated by pharmacological manipulations. For example, chronic treatment of experimental animals with various antidepressant drugs is known to cause a loss of $\beta$-adrenergic receptors in the brain, and this receptor downregulation is generally believed to be relevant to the therapeutic action of these drugs (reviewed by Chuang and Costa, 1984). However, little is known as to whether $\beta$-receptor internalization occurs in the CNS. We reasoned that if $\beta$-adrenergic receptors in the CNS are internalized by mechanisms involving coated pits, isolated coated vesicles should contain these binding sites. In this report we present evidence for the association of $\beta$-adrenergic receptors with purified coated vesicles and show that the characteristics of these receptors differ in some respects from those found in synaptic plasma membranes (SPM).

\section{Materials and Methods}

Isolation of coated vesicles

Coated vesicles were isolated from bovine forebrain (freshly obtained from a local slaughterhouse) using the procedures of Pfeffer and Kelly (1985). Briefly, 2 brains (about $600 \mathrm{gm}$ ) were dissected to remove the 
meninges and homogenized in an equal volume of homogenization buffer (see below). The crude microsomal $(100,000 \times g)$ pellet obtained from $20,000 \times g$ supernatant was subjected to 3 successive continuous $\mathrm{D}_{2} \mathrm{O}-$ Ficoll gradient centrifugations $\left(9 \% \mathrm{D}_{2} \mathrm{O}-2 \%\right.$ Ficoll to $90 \% \mathrm{D}_{2} \mathrm{O}-$ $20 \%$ Ficoll). The resulting coated vesicle-enriched preparation (60-80\%) was applied to a controlled pore glass bead permeation column $(1.5 \times$ $110 \mathrm{~cm}$; mean pore diameter, $205 \mathrm{~nm}$ ) to achieve further purification. Two protein peaks were eluted from the column and were monitored by electron microscopy and SDS-PAGE (see Results). Materials present in peak II of the column are referred to as coated vesicles. Peaks I and II obtained from the column were frozen immediately at $-70^{\circ} \mathrm{C}$ until use. The yields of protein in peaks I and II were about 300 and $700 \mu \mathrm{g} /$ $100 \mathrm{~g}$ of brain, respectively.

\section{Binding of $\beta$-adrenergic receptor ligands to peaks $I$ and $I I$ and synaptic plasma membranes}

Assay mixtures in a final volume of $0.5 \mathrm{ml}$ contained $25 \mathrm{mM}$ Tris $\mathrm{HCl}$ buffer, $\mathrm{pH} 7.4,1 \mathrm{mM} \mathrm{MgCl}$ and indicated concentrations of membrane proteins and either ${ }^{125} \mathrm{I}-d l$-cyanopindolol $(\mathrm{CYP} ; 2200 \mathrm{Ci} / \mathrm{mmol}$; New England Nuclear, Boston, MA) or ${ }^{3} \mathrm{H}-\mathrm{CGP} 12177$ (38 Ci/mmol; Amersham, Arlington Heights, IL). The binding reaction was terminated after incubation at $30^{\circ} \mathrm{C}$ for $45 \mathrm{~min}$; at this time, the specific binding of both ligands had attained an equilibrium. For the binding to peak I or II, the reaction mixture was immediately applied to a Sepharose CL 4B (Pharmacia, Piscataway, NJ) column $(0.6 \times 13 \mathrm{~cm})$ that had been equilibrated with the above Tris $\mathrm{MgCl}_{2}$ buffer at $4^{\circ} \mathrm{C}$. The eluate appearing at the void volume, which contained radioligand bound to sites in peak I or II, was collected for the determination of radioactivity in a $\gamma$ - or $\beta$-counter for ${ }^{125} \mathrm{I}$ and ${ }^{3} \mathrm{H}$, respectively. Details of these experimental procedures are as described previously (Chuang and Costa, 1979; Chuang et al., 1981). Nonspecific binding was measured in the presence of $2 \mu \mathrm{M}$ unlabeled alprenolol and was subtracted from the total binding to obtain specific binding (70-90\% of the total binding). For the measurement of $\beta$-receptor binding to sites in peaks I and II, the column assay was found to be far more consistent and to produce a higher degrce of spccific binding than the method of filtration through glass fiber filter. Because of the size heterogeneity of membrane fragments present in the SPM preparation, binding of $\beta$-receptor ligands to SPM was measured using the conventional glass fiber filtration method.

\section{Adenylate cyclase assays}

Adenylate cyclase activities present in SPM and peaks I and II were assaycd in $100 \mu \mathrm{l}$ of reaction mixture containing $25 \mathrm{~mm}$ Tris $\mathrm{HCl}$ buffer, pH 7.4, $10 \mathrm{~mm} \mathrm{MgCl}_{2}, 1 \mathrm{~mm}$ EDTA, $0.1 \mathrm{~mm}$ ATP, 2 mм phosphocreatine, 16 units $/ \mathrm{ml}$ creatine phosphokinase, $0.5 \mathrm{~mm}$ isobutylmethylxanthine, indicated amounts of protein from SPM and peaks I or II, and, when indicated, $10^{-4} \mathrm{M} \mathrm{GTP} \pm 2 \times 10^{-4} \mathrm{M}(-)$-isoproterenol hydrochloride. After incubation at $37^{\circ} \mathrm{C}$ for $15 \mathrm{~min}$, the reaction was terminated by addition of $40 \mu \mathrm{l}$ of $0.33 \mathrm{M} \mathrm{ZnSO}_{4}$ and $40 \mu \mathrm{l}$ of $0.5 \mathrm{M}$ $\mathrm{Na}_{2} \mathrm{CO}_{3}$ followed by centrifugation to remove the precipitate. An aliquot of $100 \mu \mathrm{l}$ of the supernatant was subjected to acetylation and the acetylated cAMP content was determined by radioimmunoassay using rabbit antibodies raised against $2^{\prime}-O$-succinyl-cAMP as reported (Harper and Brooker, 1975). The amounts of cAMP present in SPM, and peak I or II at incubation time zero were considered as the background and subtracted; these values were less than $0.4 \mathrm{pmol} / \mathrm{mg}$ protein. The reaction was lincar up to $20 \mathrm{~min}$ when incubated at $37^{\circ} \mathrm{C}$.

\section{Procedures for the treatment of coated vesicles with $0.5 \mathrm{M}$ Tris}

About $5 \mathrm{mg}$ protein obtained from peak II of the controlled glass bead permeation column was diluted with an equal volume of homogenization buffer (10 mM HEPES, pH 7.4, $0.1 \mathrm{~mm} \mathrm{MgCl}_{2}, 150 \mathrm{~mm} \mathrm{NaCl}$, $1 \mathrm{~mm}$ EGTA) and centrifuged at $100,000 \times g$ for $1 \mathrm{hr}$. Half of the resulting pellets were resuspended in $5 \mathrm{ml}$ of homogenization buffer, and the remainder was added to the same volume of homogenization buffer containing $0.5 \mathrm{M}$ Tris $\mathrm{HCl}, \mathrm{pH} 7.4$. After incubation at room temperature for $30 \mathrm{~min}$, these mixtures were centrifuged at $150,000 \times$ $g$ for $1 \mathrm{hr}$. The supernatants were collected for protein analysis, and the pellets were individually resuspended in a small volume of the column buffer (10 mm HEPES, pH 7.0, $200 \mathrm{~mm}$ sucrose, $300 \mathrm{~mm} \mathrm{NaCl}, 10 \mathrm{~mm}$ EGTA) and rechromatographed on 2 glass bead permeation columns run in parallel. Peaks I and II derived from Tris-treated and control coated vesicles were centrifuged at $200,000 \times g$ for $4 \mathrm{hr}$ and the pellets resuspended in a small volume of homogenization buffer for protein

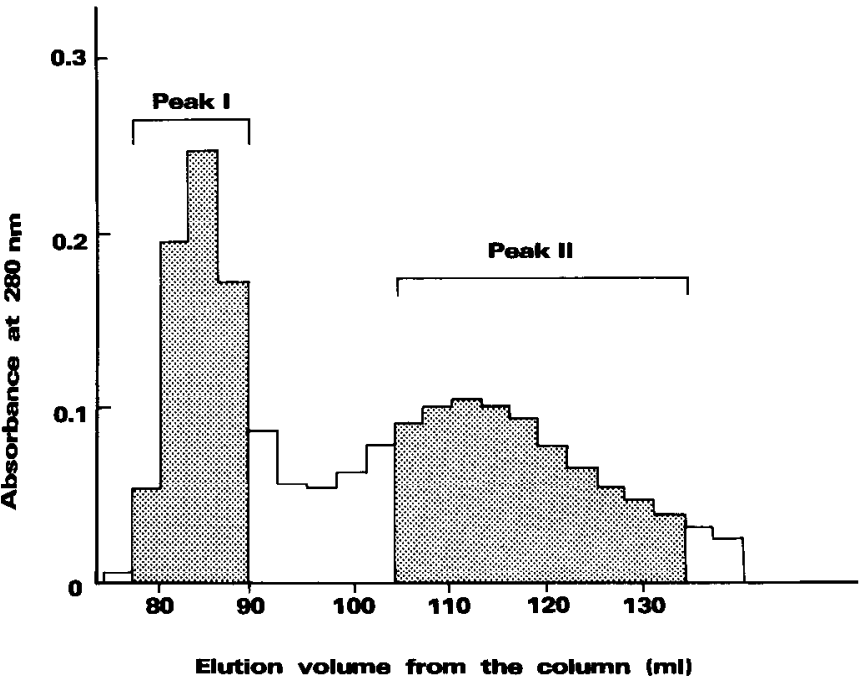

Figure 1. Chromatography of a coated vesicle-enriched preparation from a controlled pore glass bead column. Coated vesicles (about 8-10 $\mu$ g protein) purified through 3 successive cycles of $\mathrm{D}_{2} \mathrm{O}-$ Ficoll density gradient centrifugations were chromatographed onto a glass bead column and eluted with the column buffer (see Materials and Methods). The flow rate was $6 \mathrm{ml} / \mathrm{hr}$. Fractions as shown were pooled to form preparations of peaks I and II. Peak I corresponded to the void volume of the column.

determination, adenylate cyclase assay, and $\beta$-adrenergic receptor binding activity measurement.

\section{Electron microscopy}

Samples of peaks I and II derived from the glass bead column were resuspended in a fixative solution containing $1 \%$ paraformaldehyde and $1 \%$ glutaraldehyde in $0.1 \mathrm{M}$ sodium cacodylate, $\mathrm{pH} 7.4$, and placed in the cold for $1 \mathrm{hr}$. The fixed material was rinsed in sodium cacodylate, postfixed in $1 \% \mathrm{OsO}_{4}$ for $1 \mathrm{hr}$, and dehydrated in a series of graded ethanols and propylene oxide. Final embedding was carried out in EpoxAraldite (Fullam). Thin sections were cut with a diamond knife on a LKB III Ultramicrotome and, after staining with uranyl acetate and lead citrate, viewed with a JEOL $100 \mathrm{CX}$ EM.

\section{Other methods}

SPM were prepared from bovine hippocampal-dentate gyrus as described (Roth et al., 1982) and resuspended in the above column buffer before use. Protein was determined using the method of Lowry et al. (1951).

\section{Results}

\section{Characterization of coated vesicles isolated from bovine brain}

Since it had been reported that the high osmolarity of conventional sucrose gradient centrifugation results in loss of coated vesicle content (Nandi et al., 1983), $\mathrm{D}_{2} \mathrm{O}-$ Ficoll equilibrium gradients (Pfeffer and Kelly, 1985) were used to isolate coated vesicles from bovine brain. The resulting coated vesicle-enriched preparation was chromatographed onto a controlled pore glass bead column (Pfeffer et al., 1983) to achieve further purification. As Figure 1 shows, 2 major $A_{280} \mathrm{~nm}$ absorbing peaks with little overlap were eluted from the column. These 2 peaks were characterized by electron microscopy and SDS-PAGE. Peak II contained almost exclusively (up to $98 \%$ ) coated vesicles and some empty baskets. Coated vesicle dimensions varied from 40 to $120 \mathrm{~nm}$, with a mean value of about $60 \mathrm{~nm}$ (Fig. $2 B$ ). In contrast, peak $I$, which appeared in the void volume of the column, consisted predominantly of larger smooth vesicles, although a few coated vesicles and some filamentous structures were also found (Fig. 2A). Analysis by SDS-PAGE confirmed 

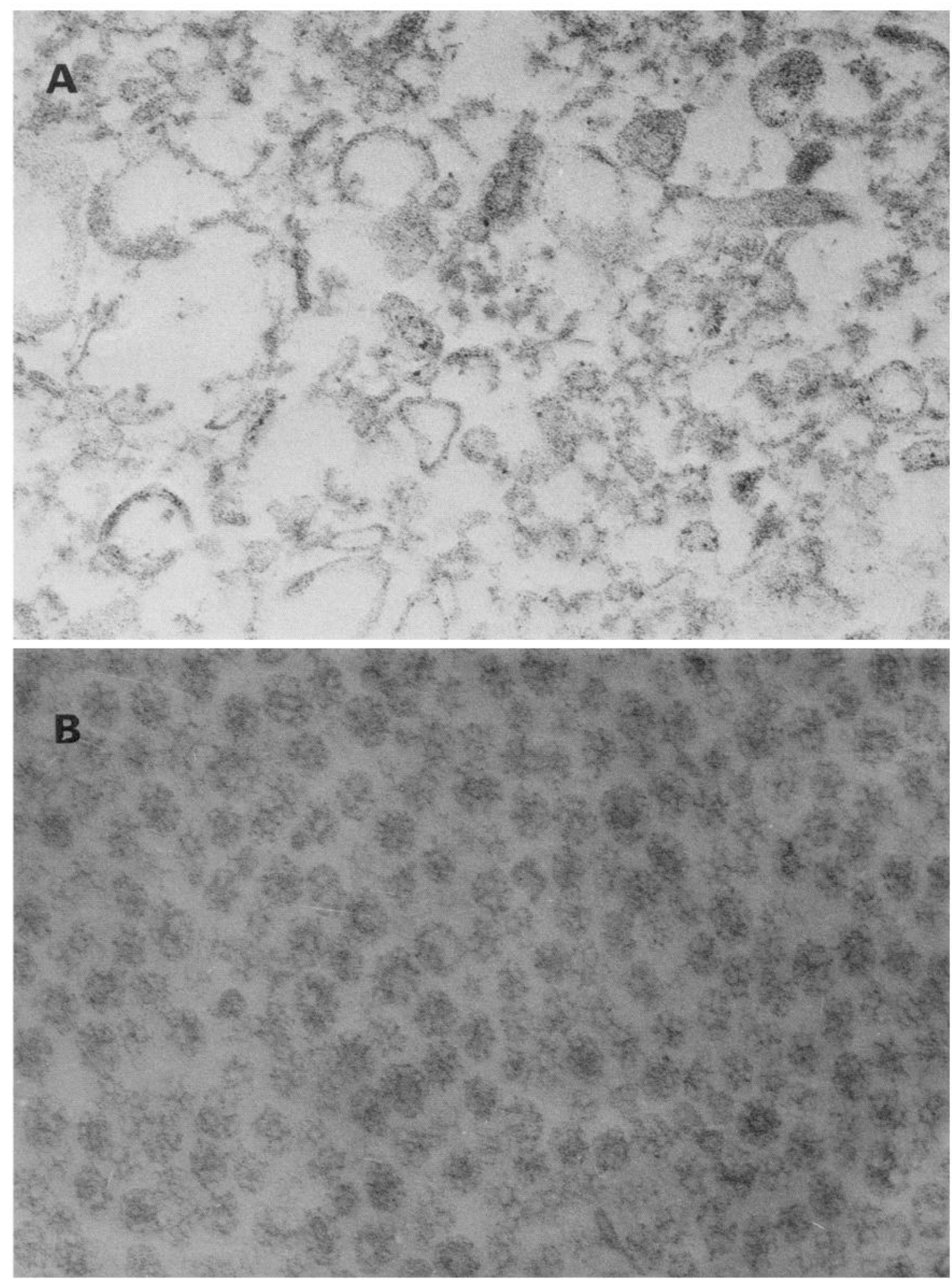

Figure 2. Electron micrographs of peaks I and II eluted from the glass bead column. $A$, The glass bead column-excluded materials (peak I) containing mostly smooth vesicles and membrane fragments. Coated vesicles were extremely rare in this fraction. $B$, Coated vesicle-enriched fraction that was retained on the column (peak II) containing almost exclusively coated vesicles and baskets with no apparent central vesicle. Occasional uncoated vesicles were seen. $\times 99,000$.

that the major protein in coated vesicles (peak II) is the clathrin heavy chain of approximately $180,000 \mathrm{Da}$ (Fig. 3). In addition, 3 protein doublets were detected with molecular weights of $110,000-100,000,55,000-50,000$, and 38,000-35,000. Peak I consisted mainly of a protein with $55,000 \mathrm{Da}$ and a relatively small quantity of the $180,000 \mathrm{Da}$ clathrin heavy chain.

\section{$\beta$-Adrenergic receptor binding activity}

To assess the presence of $\beta$-adrenergic receptor binding sites in peaks I and II, we used ${ }^{125} \mathrm{I}-\mathrm{CYP}$ as ligand and Sepharose CL 4B column chromatography to separate free CYP from CYP bound to supramacromolecular structures. As shown in Figure 
Table 1. Adenylate cyclase activity in various subcellular fractions of bovine brain

\begin{tabular}{lrrr} 
& \multicolumn{3}{l}{$\begin{array}{l}\text { cAMP formed } \\
(\mathrm{pmol} / \mathrm{mg} \text { protein/min })\end{array}$} \\
\cline { 2 - 4 } & \multicolumn{1}{c}{-GTP } & \multicolumn{1}{c}{ +GTP } & \multicolumn{1}{c}{$\begin{array}{l}\text { +GTP and } \\
\text { isoproterenol }\end{array}$} \\
Fractions & $16.3 \pm 0.4$ & $19.7 \pm 0.8$ & $22.3 \pm 1.2$ \\
Before column $(n=5)$ & $21.1 \pm 0.6$ & $23.5 \pm 1.1$ & $24.0 \pm 0.8$ \\
Peak I $(n=6)$ & $24.2 \pm 0.5$ & $25.7 \pm 0.6$ & $25.0 \pm 0.7$ \\
Peak II $(n=6)$ & $111.2 \pm 4.1$ & $156.0 \pm 6.2$ & $199.0 \pm 7.4$ \\
SPM $(n=3)$ &
\end{tabular}

Conditions of adenylate assay are described in Materials and Methods. The amounts of protein used per assay were 6-18 $\mu \mathrm{g}$ for all fractions. These protein concentrations were all in the linear range of activity.

$4 A,{ }^{125}$ I-CYP was specifically bound to sites in peaks I and II in a saturable manner, as it was to SPM. The $B_{\max }$ values calculated by Scatchard analyses from 4 separate experiments were $28 \pm 4$ and $32 \pm 3 \mathrm{fmol} / \mathrm{mg}$ protein for peaks I and II, respectively, and $172 \pm 18 \mathrm{fmol} / \mathrm{mg}$ protein for SPM (data not shown). It is seen in Figure $4 B$ that ${ }^{3} \mathrm{H}-\mathrm{CGP}$ 12177, a hydrophilic ligand for $\beta$-adrenergic receptors (Staehelin and Hertel, 1982), failed to label receptors present in peak II but was specifically bound to SPM and, to a much lesser extent, to peak I. These results suggest that $\beta$-adrenergic receptors present in coated vesicles are cryptic in nature.

The binding of ${ }^{125}$ I-CYP to peaks I as well as II and SPM was displaced effectively by (-)-alprenolol $\left(\mathrm{IC}_{50} \sim 5 \times 10^{-9} \mathrm{M}\right)$ and relatively weakly by $(-)$-isoproterenol $\left(\mathrm{IC}_{50}=2\right.$ to $\left.8 \times 10^{-6} \mathrm{M}\right)$ (Fig. 5). (+)-Isoproterenol, the stereoisomer, failed to affect this binding at $10^{-6} \mathrm{M}$ (data not shown). The addition of $50 \mu \mathrm{M}$ GppNHp was without effect on the displacement by $(-)$-isoproterenol of ${ }^{125} \mathrm{I}-\mathrm{CYP}$ binding to peak II (Fig. $5 B$ ), whereas a significant "right shift" (about 4-fold increase in $\mathrm{IC}_{50}$ ) and an increase in the steepness of the displacement curve was found when SPM was used (Fig. 5C). A similar but smaller effect of $\mathrm{GppNHp}$ on the isoproterenol displacement curve was seen in the binding of ${ }^{125}$ I-CYP to peak I (Fig. $5 A$ ). In all 3 preparations, the Hill coefficients were approaching $1(>0.88)$ when isoproterenol displacements were performed in the presence of GppNHp. The presence of GppNHp did not change the displacement behavior of alprenolol in any of the 3 preparations (Fig. 5).

\section{Activities of adenylate cyclase}

Since adenylate cyclase is a component of the $\beta$-adrenergic receptor complex, we attempted to detect it in peaks I and II, the coated vesicle enriched before column preparation, and SPM. These results are summarized in Table 1. Adenylate cyclase activities were found in both peaks I and II with specific activities of $21 \pm 0.6$ and $24 \pm 0.5 \mathrm{pmol} \mathrm{cAMP} / \mathrm{mg}$ protein $/ \mathrm{min}$, respectively. These activities were unchanged by the addition of GTP $\left(10^{-4} \mathrm{M}\right) \pm$ isoproterenol $\left(2 \times 10^{-4} \mathrm{M}\right)$. In contrast, the cyclase activity in the SPM was significantly stimulated by GTP alone (40\% increase) and in the presence of isoproterenol $(80 \%$ increase). Cyclase activities present in peaks I and II were not significantly stimulated by $10 \mathrm{~mm} \mathrm{NaF}$. These activities were dependent on incubation temperature; an incubation at $4^{\circ} \mathrm{C}$ failed to increase cAMP content. Boiling peaks I and II preparations for $3 \mathrm{~min}$ completely abolished their adenylate cyclase activity.

\section{Effect of Tris treatment on the chromatographic pattern of coated vesicles}

Since specific activities of $\beta$-adrenergic receptor binding and adenylate cyclase detected in peak I were almost equal to those found in peak II, we investigated the possibility that these peak I-associated activities might be derived from coated vesicles in peak II. Keen et al. (1979) first reported that treatment of coated

\section{Peak II I}
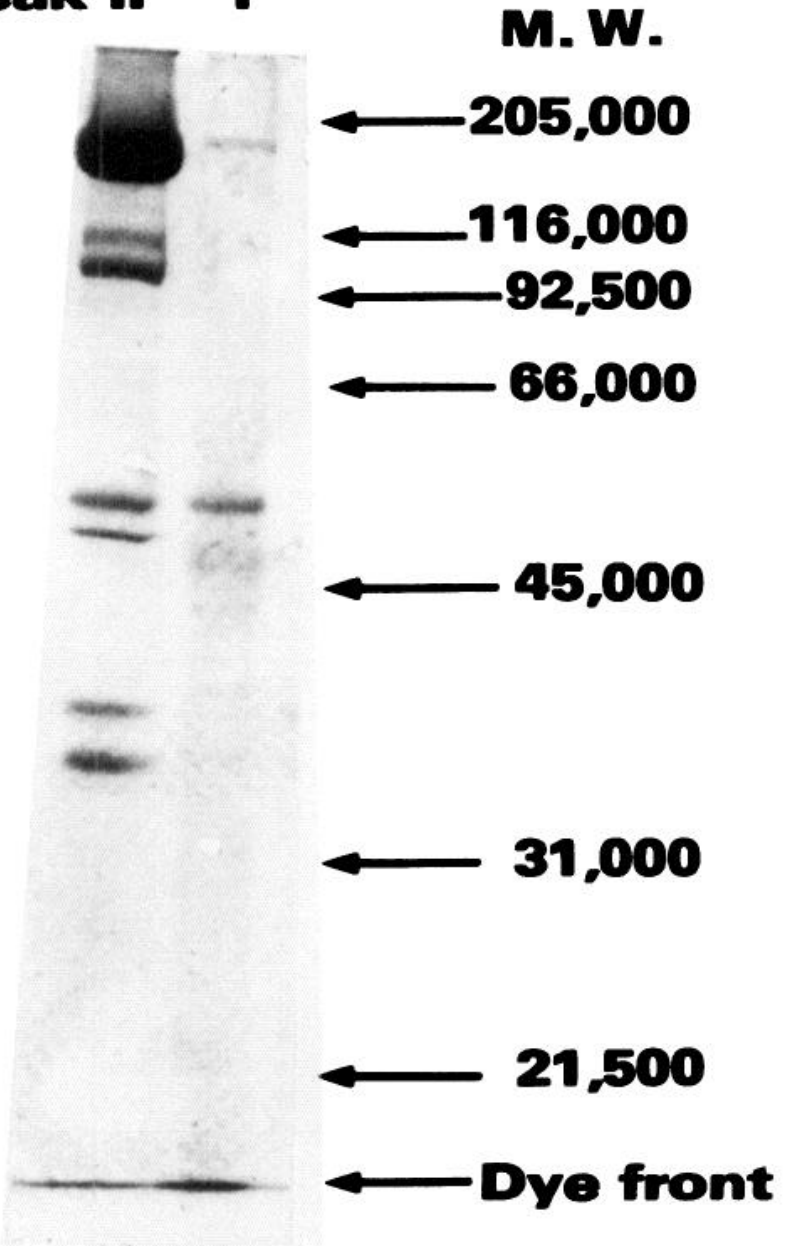

Figure 3. SDS-PAGE of peaks I and II materials. Peak I ( $15 \mu \mathrm{g}$ protein) and peak II (120 $\mu$ g protein) fractions were subjected to $10 \%$ PAGE in the presence of SDS as described (Laemmli, 1970). In order to detect minor protein components associated with the coated vesicle preparation, a greater amount of peak II was loaded onto the gel. Coomassie blue-stained proteins are shown together with positions of the following protein standards: myosin $(205 \mathrm{~K}), \beta$-galactosidase $(116 \mathrm{~K})$, phosphorylase B $(92.5 \mathrm{~K}), \mathrm{BSA}(66 \mathrm{~K})$, ovalbumin $(45 \mathrm{~K})$, carbonic anhydrase $(31 \mathrm{~K})$, and soybean trypsin inhibitor $(21 \mathrm{~K})$.

\begin{tabular}{|c|c|c|c|c|}
\hline & \multicolumn{2}{|c|}{ Tris-treated } & \multicolumn{2}{|l|}{ Control } \\
\hline & Peak I & Peak II & Peak I & Peak II \\
\hline $\begin{array}{l}\text { Protein content } \\
\quad(\mu \mathrm{g})\end{array}$ & $\begin{array}{l}182 \\
(165 \%)\end{array}$ & $\begin{array}{l}112 \\
(100 \%)\end{array}$ & $\begin{array}{l}113 \\
(73 \%)\end{array}$ & $\begin{array}{l}154 \\
(100 \%)\end{array}$ \\
\hline $\begin{array}{l}\text { 125I-CYP binding } \\
\text { (fmol bound) }\end{array}$ & $\begin{array}{r}9.34 \\
(161 \%)\end{array}$ & $\begin{array}{r}5.77 \\
(100 \%)\end{array}$ & $\begin{array}{r}4.88 \\
(62 \%)\end{array}$ & $\begin{array}{r}7.86 \\
(100 \%)\end{array}$ \\
\hline $\begin{array}{l}\text { Adenylate cyclase } \\
\text { (pmol cAMP/min) }\end{array}$ & $\begin{array}{r}5.62 \\
(190 \%)\end{array}$ & $\begin{array}{r}2.85 \\
(100 \%)\end{array}$ & $\begin{array}{r}2.83 \\
(70 \%)\end{array}$ & $\begin{array}{r}4.01 \\
(100 \%)\end{array}$ \\
\hline
\end{tabular}

Conditions of the treatment of coated vesicles with $0.5 \mathrm{M}$ Tris and the reisolation of peaks I and II from glass bead columns are described in Materials and Methods. Aliquots of peaks I and II were assayed for protein content, ${ }^{125} \mathrm{I}-\mathrm{CYP}$ binding, and adenylate cyclase activity. The data presented are from 1 experiment reproduced 3 times. 

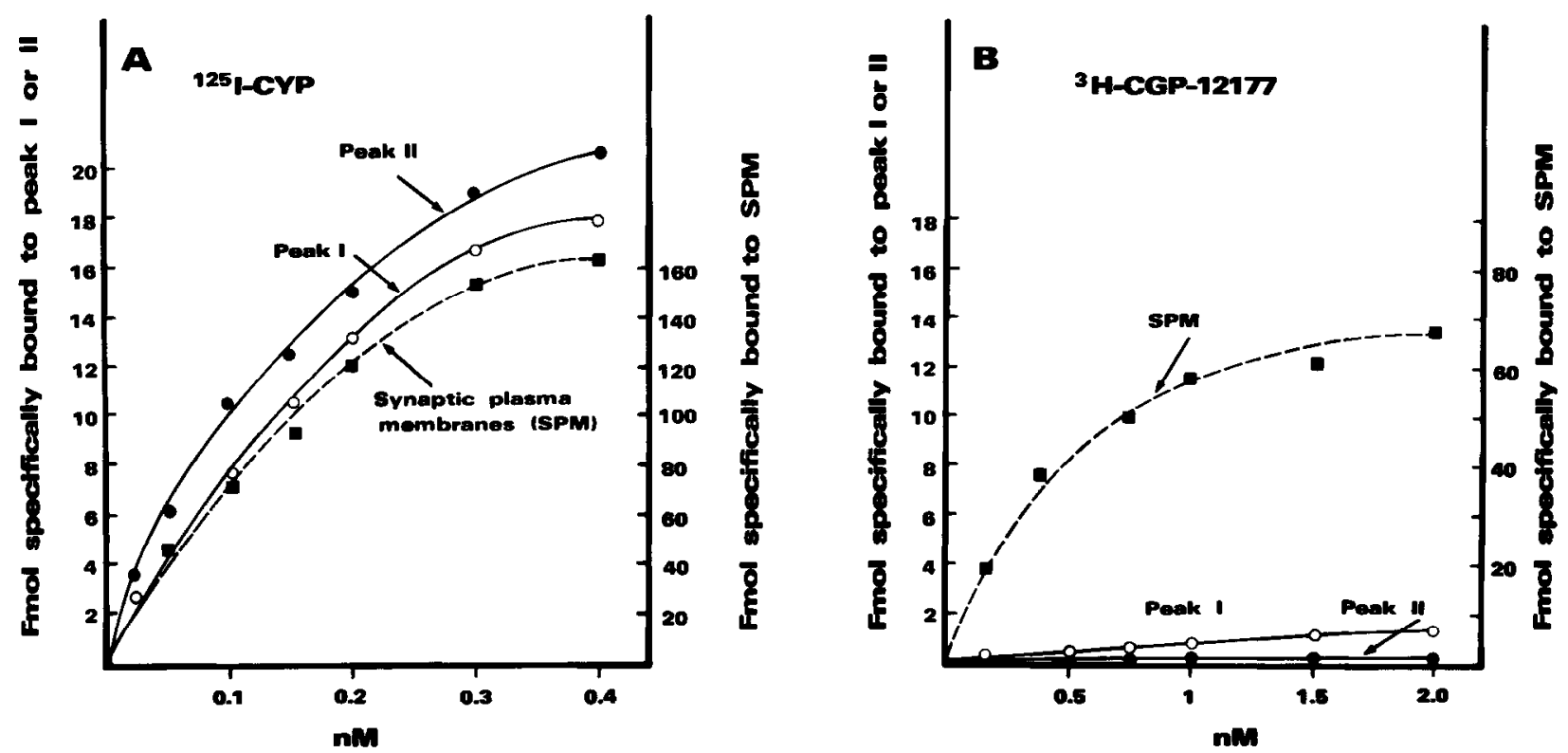

Figure 4. Binding of ${ }^{125} \mathrm{I}-\mathrm{CYP}(A)$ and ${ }^{3} \mathrm{H}-\mathrm{CGP} 12177(B)$ to pcaks I and II and synaptic plasma membranes. Procedures of the binding are as described in Materials and Methods. The amounts of protein used per assay were 36,49 , and $26 \mu \mathrm{g}$ for peaks I and II and SPM, respectively. These protein concentrations were in the linear range of activity. Nonspecific binding was determined in the presence of $2 \mu \mathrm{M}(-)$-alprenolol and subtracted from the total binding to obtain the specific binding. The specific activities of ${ }^{125} \mathrm{I}-\mathrm{CYP}$ and ${ }^{3} \mathrm{H}-\mathrm{CGP} 12177 \mathrm{were} 2810$ and $60 \mathrm{cpm} /$ fmol, respectively. The data presented are from 1 experiment that was reproduced 4 times. For the sake of accuracy in illustrating the number of binding sites, the $Y$-scales for vesicular fractions (peaks I and II) and for the SPM, are not the same.

vesicles with $0.5 \mathrm{M}$ Tris $\mathrm{HCl}$ removes clathrin and a 110,000 Da polypeptide from coated vesicles. We adopted these experimental conditions to examine whether this decoating process alters the chromatographic patterns of adenylate cyclase and $\beta$-adrenergic receptors originally associated with coated vesicles. Thus, the peak II preparation obtained from the glass bead column was pelleted by centrifugation, divided into 2 portions and resuspended; one was exposed to $0.5 \mathrm{M}$ Tris and the other was used as control. After Tris treatment, these materials were again centrifuged and the pellets were resuspended and rechromatographed on glass bead columns. As seen in Figure 6, Tris treatment drastically changed the elution pattern of coated vesicles with the majority of the proteins originally associated with peak II appearing in peak I (Fig. 6A). In the control sample, an appreciable amount (about $30 \%$ of the total) of coated vesicleassociated protein could also be recovered in peak I upon rechromatography (Fig. 6B).

SDS-PAGE analysis of the Tris extract of coated vesicles (recovered in the $150,000 \times g$ supernatant) revealed that Tris treatment removed at least 5 times more clathrin heavy and light chains and a 10,000 Da polypeptide than control (results not shown). Materials in peaks I and II of Tris-treated and control samples were reisolated by centrifugation and then assayed for protein content and activities of $\beta$-receptor binding and adenylate cyclase. The data in Table 2 show that ${ }^{125} \mathrm{I}-\mathrm{CYP}$ binding and adenylate cyclase activities were shifted in parallel with protein contents from peak II to peak I from both Tristreated and control samples.

\section{Discussion}

In the present study, we presented evidence for the occurrence of $\beta$-adrenergic receptor binding sites in a coated vesicle preparation obtained from bovine brain. Coated vesicles were isolated by $\mathrm{D}_{2} \mathrm{O}$-Ficoll gradient centrifugation to preserve the integrity of structures and by glass bead column chromatography to remove uncoated materials. The purity of coated vesicles was verified by electron microscopy and SDS-PAGE (Figs. 2, 3). ${ }^{125} \mathrm{I}$-CYP binding to $\beta$-adrenergic receptors in the purified coated vesicle preparation was displaced potently by (-)-alprenolol and relatively weakly by isoproterenol in a stereospecific manner, as was binding to SPM (Fig. 5). However, the characteristics of $\beta$-adrenergic receptor binding associated with the peak II preparation differ from those of SPM in 2 regards: (1) The displacement of CYP binding by (-)-isoproterenol was unaffected by the addition of guanine nucleotides and contrasted with the "right shift" observed with SPM (Fig. 5); and (2) ${ }^{3} \mathrm{H}-\mathrm{CGP} 12177$, a hydrophilic ligand that labels only cell-surface receptors because of its inability to traverse membrane, bound to receptors in SPM but not with those in the coated vesicle preparation (Fig. 4), suggesting the presence of "latent" receptors in coated vesicles. Latency of receptors for low-density lipoprotein and insulin has also been shown in isolated coated vesicles (Mello et al., 1980; Pilch et al., 1983). In these studies, latent receptors were unmasked by pretreatment of coated vesicles with octylglucoside. Since we found that octyl-glucoside severely damages $\beta$-adrenergic receptors present in coated vesicles and other preparations, we were unable to use this detergent to unmask receptors in our study. It is interesting to note that the binding characteristics of the coated vesicle preparation-i.e., the potency of $(-)$-isoproterenol for binding displacement, the slope of the displacement curve, and the lack of effect of guanine nucleotide on the isoproterenol binding-are similar to those found in "internalized" $\beta$-adrenergic receptors present in vascular structures derived from frog erythrocytes desensitized with $\beta$-adrenergic agonists (Chuang et al., 1981; Stadcl et al., 1983). It should, however, be noted that a 6-fold lower density of ${ }^{125}$ ICYP binding sites was found in coated vesicles than in the plasma membranes (Fig. 4), suggesting that only a small fraction of coated vesicles are involved in $\beta$-receptor transport. These results are not surprising because this purified population of coated vesicles is extremely heterogenous; they may arise from various types of neurons and several classes of glial cells.

Adenylate cyclase activity was also detected in the coated vesicle preparation. Furthermore, this cyclase activity was unchanged by the addition of GTP or GTP plus isoproterenol, whereas these agents elicited a significant activation of the ac- 


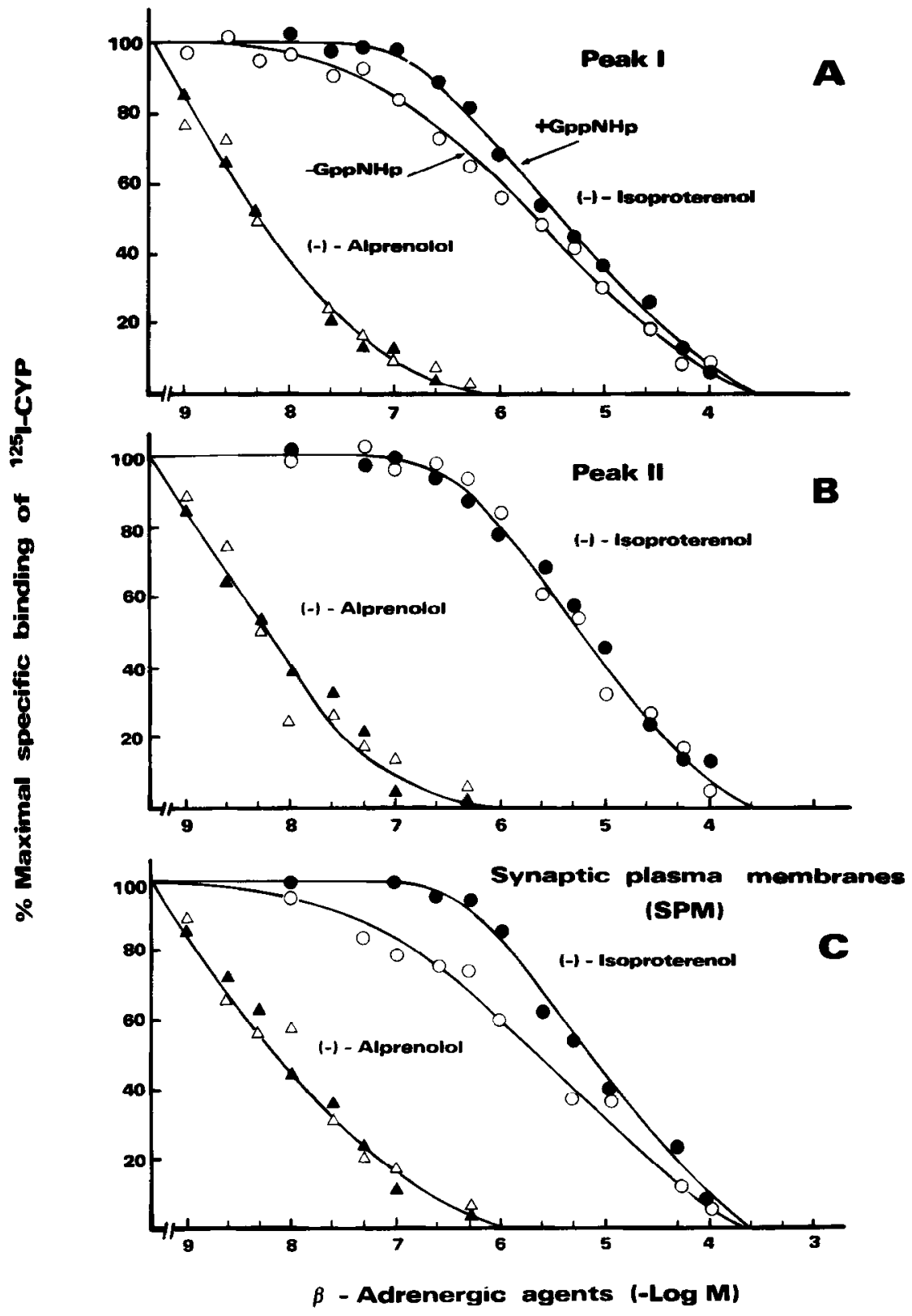

Figure 5. Effects of GppNHp on the displacement by $(-)$-isoproterenol and $(-)$-alprenolol of ${ }^{125}$ I-CYP binding to peak I $(A)$, peak II $(B)$, and synaptic plasma membranes $(C)$. Procedures of the binding are as described in Materials and Methods. The concentration of ${ }^{125}$ I-CYP was $200 \mathrm{pm}$ and amounts of proteins used were 30,25 , and $15 \mu \mathrm{g}$ for peaks I and II and SPM, respectively. When used, the concentration of GppNHp was $50 \mu \mathrm{M}$. ${ }^{125} \mathrm{I}-$ CYP binding that was not displaced by $2 \times 10^{-6} \mathrm{M}(-)$-alprenolol or $2 \times$ $10^{-4} \mathrm{M}(-)$-isoproterenol was considered as nonspecific binding and subtracted from the total binding. The $100 \%$ values of the specific binding were 16,18 , and $105 \mathrm{fmol} / \mathrm{mg}$ protein for peaks I and II and SPM, respectively. The specific activity of ${ }^{125}$ I-CYP was $2613 \mathrm{cpm} / \mathrm{fmol}$. The data presented are from 1 experiment that was reproduced 3 times.

tivity in SPM (Table 1). These results support the notion that the adenylate cyclase present in coated vesicles is uncoupled from the guanine nucleotide binding protein (Ns) and the $\beta$ receptor binding site, thus arguing against the possibility that activities of cyclase and receptor binding are due to insertion into or contamination of coated vesicles with fragments of plasma membranes during the isolation procedure. To our knowledge, these results represent the first time that this enzyme has been localized in brain coated vesicles, and they differ from those reported by Hadjiivanova et al. (1984) who suggested an entirely plasma membrane origin of adenylate cyclase in the liver.

The properties of $\beta$-receptor binding site and adenylate cyclase present in the peak I preparation are reminiscent of those found in the peak II; however, their precise origin requires further investigation. Electron micrographs show that the peak I preparation was heterogenous, containing mainly smooth vesicles, some filamentous structurcs and a few coated vesicles (Fig. 2). It is generally agreed that the clathrin coats are lost very rapidly from coated vesicles in vivo, probably within a minute after coated vesicle formation (Pearse and Bretscher, 1981). Moreover, an ATP-dependent uncuating enzyme that has been purified appears to form a stoichiometric complex with the clathrin trimer (Schmid et al., 1984). Thus, one may speculate that the molecular entities of cyclase and receptor detected in peak I may be located in smooth vesicles that are derived from coated vesicles by removal of clathrin and aggregation. The results of experiments presented in Figure 6 and Table 2 may support this view. When peak II material was rechromatographed onto a glass bead column, considerable amounts of protein, $\beta$-receptor binding, and cyclase activities were recovered in peak I. Pretreatment of peak II with $0.5 \mathrm{M}$ Tris, which facilitated the removal of clathrin from coated vesicles, resulted in a pronounced shift in the absorbance profile and the transfer of binding and cyclase activities from peak II to I.

The size of coated vesicles used in this study varied from about 40 to $120 \mathrm{~nm}$. In certain tissucs, e.g., liver and adrenal cortex, large coated vesicles $(90-120 \mathrm{~nm})$ are derived from plas- 


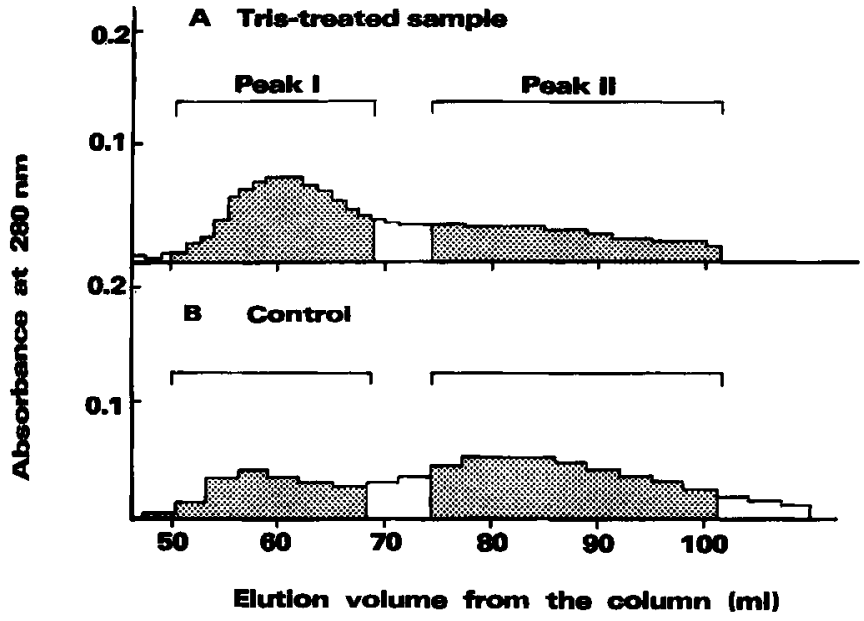

Figure 6. Rechromatography of coated vesicles from controlled pore glass bead columns. Coated vesicles from a peak II preparation were pelleted by centrifugation and then resuspended in the homogenization buffer with $(A)$ or without $(B) 0.5 \mathrm{M}$ Tris $\mathrm{HCl}, \mathrm{pH} 7.4$. After incubation at room temperature for $30 \mathrm{~min}$, the 2 preparations were centrifuged and pellets were resuspended and rechromatographed onto 2 glass columns run in parallel. The $280 \mathrm{~nm}$ absorbance of the column eluant was recorded. Details of the experimental procedures are as described in Materials and Methods.

ma membranes and involved in receptor-mediated endocytosis, whereas small coated vesicles $(50-80 \mathrm{~nm})$ are probably of Golgi origin and participate in intracellular transport and receptor recycling (Goldstein et al., 1979; Pearse and Bretscher, 1981). At present, it is unclear whether we can associate the size of coated vesicles in the brain with their origin in plasma membrane or Golgi apparatus. Nor do we know whether large or small coated vesicles contain $\beta$-receptor and/or adenylate cyclase. Further studies using a morphological approach will be essential to identify the origin of these molecular entities and to aid our understanding of whether these entities are involved in endocytosis or exocytotic intracellular transport.

\section{References}

Bennett, D. B., J. W. Spain, M. B. Laskowski, B. L. Roth, and C. J. Coscia (1985) Stereospecific opiate binding sites occur in coated vesicles. J. Neurosci. 5: 3010-3015.

Bursztan, S., and G. D. Fischbach (1984) Evidence that coated vesicles transport acetylcholine receptors to the surface membrane of chick myotubes. J. Cell Biol. 98: 498-506.

Chuang, D.-M., and E. Costa (1979) Evidence for internalization of the recognition site of $\beta$-adrenergic receptors during receptor subsensitivity induced by $(-)$-isoproterenol. Proc. Natl. Acad. Sci. USA 76: 3024-3028.

Chuang, D.-M., and E. Costa (1984) Recognition sites of antidepressant drugs. In Handbook of Neurochemistry, Vol. 6, Abel Lajtha, ed., pp. 307-330, Plenum, New York.

Chuang, D.-M., W. J. Kinner, L. Farber, and E. Costa (1981) A biochemical study of receptor internalization during $\beta$-adrenergic receptor desensitization in frog erythrocytes. Mol. Pharmacol. 18: 348355.

Fine, R. E., and C. D. Ockleford (1984) Supramolecular cytology of coated vesicles. Int. Rev. Cytol. 91: 1-43.

Garbern, J. Y., and J.-Y. Wu (1981) Purification and characterization of clathrin from bovine brain. J. Neurochem. 36: 602-612.

Goldstein, J. L., R. G. W. Anderson, and M. S. Brown (1979) Coated pits, coated vesicles and receptor-mediated endocytosis. Nature 279. 679-685.

Hadjiivanova, N., N. Flint, and W. H. Evans (1984) Endocytosis of $\beta$-adrenergic ligands by rat liver: Comparison of $\beta$-adrenergic receptor and adenylate cyclase distribution in endosome and plasma-membrane fractions. Biochem. J. 222: 749-754.

Harden, T. K., C. U. Cotton, G. L. Waldo, J. K. Lutton, and J. P. Perkins (1980) Catecholamine-induced alteration in the sedimen- tation behavior of membrane-bound $\beta$-adrenergic receptors. Science 210: 441-443.

Harper, J. F., and G. Brooker (1975) Femtomole sensitive radioimmunoassay for cyclic AMP and cyclic GMP after $2^{\prime} O$ acetylation by acetic anhydride in aqueous solution. J. Cyclic Nucleotide Res. I: 207-218.

Keen, J. H., M. C. Willingham, and I. H. Pastan (1979) Clathrincoated vesicles: Isolation, characterization and factor-dependent reassociation of clathrin baskets. Cell 16: 303-312.

Laemmli, U. K. (1970) Cleavage of structural proteins during assembly of the head of bacteriophage $T_{4}$. Nature 227: 680-685.

Lowry, O. H., N. J. Rosebrough, A. L. Farr, and R. J. Randall (1951) Protein determination with the Folin phenol reagent. J. Biol. Chem. 193: 265-275.

Mahan, L. C., A. M. Koachman, and P. A. Insel (1985) Genetic analysis of $\beta$-adrenergic receptor internalization and down-regulation. Proc. Natl. Acad. Sci. USA 82: 129-133.

Mello, R. J., M. S. Brown, J. L. Goldstein, and R. G. W. Anderson (1980) $\mathrm{LDL}$ receptors in coated vesicles isolated from bovine adrenal cortex: Binding sites unmasked by detergent treatment. Cell 20:829837.

Nandi, P. K., G. Irace, P. V. Van Jaarsveld, R. E. Lippoldt, and $H$. Edelhach (1983) Instability of coated vesicles in concentrated sucrose solutions. Proc. Natl. Acad. Sci. USA 79: 5881-5885.

Palade, G. E., and M. Fletcher (1977) Reversible alterations in the morphology of the Golgi complex induced by the arrest of secretory transport. J. Cell Biol. 75: 371 a.

Pearse, B. M. F. (1976) Clathrin: A unique protein associated with intracellular transfer of membrane by coated vesicles. Proc. Natl. Acad. Sci. USA 73: 1255-1259.

Pearse, B. M. F. (1982) Coated vesicles from human placenta carry ferritin, transferrin and immunoglobulin G. Proc. Natl. Acad. Sci. USA 79 : 451-455.

Pearse, B. M. F., and M. S. Bretscher (1981) Membrane recycling by coated vesicles. Annu. Rev. Biochem. 50: 85-101.

Pfeffer, S. R., and R. B. Kelly (1985) The subpopulation of brain coated vesicles that carries synaptic vesicle proteins contains two unique polypeptides. Cell 40: 949-957.

Pfeffer, S. R., D. G. Drubin, and R. B. Kelly (1983) Identification of three coated vesicle components as $\alpha$ - and $\beta$-tubulin linked to a phosphorylated 50,000-dalton polypeptide. J. Cell Biol. 97: 40-47.

Pilch, P. F., M. A. Shia, R. J. J. Benson, and R. E. Fine (1983) Coated vesicles participate in the receptor-mediated endocytosis of insulin. J. Cell Biol. 93: 133-138.

Pittman, R. N., and P. B. Molinoff (1980) Interactions of agonists and antagonists with $\beta$-adrenergic receptors on intact $\mathrm{L}_{6}$ muscle cells. $J$. Cyclic Nucleotide Res. 6: 421-435.

Porter-Jordan, K., R. J. J. Benson, and R. E. Fine (1982) Localization of the acetylcholine receptor and acetylcholinesterase in coated vesicles. J. Cell Biol. 95: 405a.

Roth, B. L., M. B. Laskowski, and C. J. Coscia (1982) Microsomal opiate receptors differ from synaptic membrane receptors in proteolytic sensitivity. Brain Res. 250: 101-109.

Roth, T. F., and K. R. Porter (1964) Yolk protein uptake in the oocyte of mosquito Aedes aegypti. J. Cell Biol. 20: 313-332.

Rothman, J. E., and R. E. Fine (1980) Coated vesicies transport newly synthesized membrane glycoproteins from endoplasmic reticulum to plasma membrane in two successive stages. Proc. Natl. Acad. Sci. USA 77: 780-784.

Rotundo, R., and D. M. Fambrough (1980) Secretion of acetylcholinesterase: Relation to acetylcholine receptor metabolism. Cell 22 : 595-602.

Schmid, S. L., W. A. Braell, D. M. Schlossman, and J. E. Rothman (1984) A role for clathrin light chains in the recognition of clathrin cages by "uncoating" ATPase. Nature 311: 228-231.

Stadel, J. M., B. Strulovici, P. Nombi, T. N. Lavin, M. M. Briggs, M. G. Caron, and R. J. Lefkowitz (1983) Desensitization of the $\beta$-adrenergic receptors of frog erythrocytes: Recovery and characterization of the down-regulated receptor in sequestered vesicles. J. Biol. Chem. 258: 3032-3038.

Staehelin, M., and C. Hertel (1982) ${ }^{3} \mathrm{H}-\mathrm{CGP}$-12177; A $\beta$-adrenergic ligand suitable for measuring cell surface receptors. J. Receptor Res. 3: 35-43.

Wood, J. W., M. P. Woodward, and T. F. Roth (1978) Common features of coated vesicles from dissimilar tissues: Composition and structure. J. Cell Sci. 30: 87-97. 